\title{
Fiscal federalism 2016 Making decentralisation work
}

HANSJÖRG BLÖCHLIGER and JUNGHUN KIM (Eds.)

OECD/Korea Institute of Public Finance, Paris, 2016, pp. 148

Book review by BRANKO STANIĆ*

https://doi.org.10.3326/pse.41.2.6

\footnotetext{
Received: May 4, 2017
}

Accepted: May 25, 2017

Branko STANIĆ, M.A.

Institute of Public Finance, Smičiklasova 21, 10000 Zagreb, Croatia

e-mail: branko.stanic@ijf.hr

ORCID iD: 0000-0002-8746-6764 

in which institutional frameworks and to what extent fiscal autonomy of sub-central governments (hereinafter: SCGs) is desirable and possible on both the expenditure and the revenue sides. The book is the latest publication by Fiscal Federalism Network, created in 2004 with the aim of providing OECD countries with analytical and statistical support and facilitating decision-making in the organization of fiscal relations across levels of government. Each of the six accessible and easy-to-read chapters abounds with case studies and cross-country analyses, consistently with the purpose of the book - to analyse and propose reform options for intergovernmental fiscal frameworks and sub-central public finance.

What is the extent to which SCGs are given autonomy? The first chapter provides an overview of fiscal decentralization and intergovernmental fiscal reforms in $O E C D$ countries. It is emphasized that standard fiscal indicators - such as subcentral spending and revenue shares or the size and composition of intergovernmental grants - are insufficient for an assessment of the multidimensional concept of fiscal decentralization. This is why a proposal to use the new, institutional indicators - such as tax autonomy, spending power or intergovernmental grant conditionality - can be seen as a completely new approach to the assessment of fiscal decentralization. While standard indicators are based solely on the fiscal capacities of SCGs, new indicators are defined by their institutional capacities and relations with upper-tier government. This makes particular sense in countries where tastes, preferences and attitudes towards the public sector vary according to jurisdictions.

Fiscal rules and frameworks are concerned with how historical turning points can create the basis for constitutional reform options in today's environment. Although constitutional set-ups vary widely from one country to another, all differences can be reduced to a single dimension - the level of constitutional decentralization, within which three types of federation are distinguished: decentralized, integrated and (somewhere in-between) quasi-decentralized. This chapter contributes to the understanding of intergovernmental relations and fiscal decentralization by emphasizing the need for coherence of fiscal constitutions - for example, how much spending autonomy matches tax autonomy or whether fiscal rules are aligned with the fiscal responsibility of state and local governments. Although fiscal constitution is a country-specific term, some common elements are highlighted on the path toward greater coherence, which should be useful to policy makers in the implementation of constitutional or other policy reforms.

Chapter 3 addresses the opportunities and challenges of property taxation as a typical local tax. Since upper-tier governments determine the tax base, any reform of property tax regimes must therefore be tied to reforms of intergovernmental fiscal frameworks. That is why part of this chapter is about a property tax that is revenue neutral, which requires amendments to both spending and taxation across all tiers of government. Although in most OECD countries, since 2008, property tax as a share of sub-central tax has begun to rise again, due to different fiscal 
constitutions, frameworks and rules, the chapter concludes that property tax reform is deeply country-specific and must be carefully implemented to fit specific circumstances. Therefore, it is a great challenge to find common elements of reform options for all OECD countries, especially considering different constitutional settings in unitary and federal governments.

Taxes or grants: which revenue source for sub-central governments? SCGs are trying to establish a balance between own taxes and intergovernmental transfers, which is conditioned by decisions at all levels of government. Although the importance of own sources of funding is clear, the chapter also states that intergovernmental grants still have a role to play, as they can help reduce differences in tax raising capacity or inter-jurisdictional externalities. However, for that purpose they would have to be around half of their current size. First, if the fiscal autonomy and spending power of SCGs (and thus own tax revenues) increase, the role of intergovernmental grants becomes less important. Grants do not give SCGs much freedom to decide on their spending levels. Second, unlike grants, own taxes increase government accountability and may affect citizens' greater involvement in budget processes. This is because most grants are earmarked for specific purposes and citizens have no impact on the allocation of these funds. Third, reliance on grants affects SCGs' sustainability as, unlike own taxes, grants tend to ease the budget constraint and lead to overspending.

Chapter 5 discusses a very important topic in the context of fiscal decentralization - monitoring SCG borrowing. It explores and analyses how different SCG borrowing mechanisms work in OECD countries. Among other things, the most discussed are fiscal rules and direct control by higher levels of government. The chapter is permeated with useful examples of completed and started fiscal reforms and expenditure and debt restrictions. Also, one box is devoted to the effects of bailout expectations - a situation of economic stress when SCGs may expect central governments to bail them out with additional resources, which again points to the importance of the adequate establishment and management of intergovernmental fiscal relations.

Finally, the last chapter presents the definition, scope and preliminary results of a pilot study on the extent to which SCGs enjoy autonomy in the design of public services. The chapter provides evidence of the limited power of SCGs over their own spending that could have negative effects on public service efficiency. The study was carried out in a five countries ${ }^{1}$ in 2009 and has resulted in the introduction of a new SCG spending power indicator. Since the spending power of SCGs is largely determined by the legal frameworks, rules and regulations of the upper tier government, the new indicator takes into account different categories of autonomy, which should explain the extent of control that SCGs exert over the

\footnotetext{
${ }^{1}$ Of the five countries taken in the pilot study, Germany and Switzerland are federal and Denmark, Portugal
} and the Slovak Republic are unitary. 
budget. The main findings show that spending power varies across countries and services and is often shared. However, the final indicator seems not yet to have been determined, although the results of the pilot study and its possible application to more countries in future studies can only contribute to the re-design of individual elements of spending responsibility across all tiers of government. In that sense, this chapter makes the biggest contribution of the entire book.

In general, the book is very well structured, divided into six, clearly presented chapters. Though the chapter contents can act as separate stories, what pervades each of them is the importance of adequate fiscal constitutions so that relations between central and sub-central governments can support fiscal decentralization and the autonomy of SCGs. In this book, the reader is confronted with the compilation of some of the most salient policy issues in fiscal federalism, where many examples illustrate the current fiscal policies, but also the policy reform options. For example, chapter 3 provides guidelines for reforming the tax on immovable property that can contribute to a strategic shift away from taxation of labour towards less distorting taxes.

Compared to the previous edition of fiscal federalism - OECD (2013) where the main contribution was the guidelines for fiscal reform based on the set of country case studies in Blöchliger and Vammalle (2012) - this book seems to be much more specific in developing a new institutional indicator for measuring the spending power of SCGs. Although the spending power indicator tree is applied to only the five countries in the pilot study, application to a number of countries would probably help re-design the assignment of spending responsibility at all levels of government. Therefore, the book is mandatory reading for all policy makers and is also useful for individuals, civil society groups, professional associations and the private sector. The book should also be of particular interest to all citizens concerned with their local community in order to get acquainted with legal possibilities and constraints and the possibilities of engaging in decision-making processes at the local level.

Although budget transparency and public participation are mentioned in certain parts of some chapters (e.g. chapter 5 on transparency and chapter 4 on civic engagement), the impression remains that much more devotion should have been made to this topic. In order for public finances to become more efficient, equitable and sustainable, greater government accountability and citizens' trust are needed. Due to this, local budget transparency can serve as the basis and the first step for direct public participation in budget processes in order for a more efficient resource allocation to be achieved. For if citizens are satisfied with the services they receive, the level of autonomy, intergovernmental relations and spending power remain at the level of concept. 


\section{REFERENCES}

1. Blöchliger, H. and Vammalle, C., 2012. Reforming Fiscal Federalism and Local Government: Beyond the Zero-Sum Game. Paris: OECD. Available at: <http:// www.keepeek.com/Digital-Asset-Management/oecd/taxation/reforming-fiscalfederalism-and-local-government_9789264119970-en\#.WRw-Ymh96Uk \#page3>.

2. OECD, 2013. Fiscal Federalism 2014: Making Decentralisation Work. Paris: OECD. Available at: <http://www.keepeek.com/Digital-Asset-Management/oecd/ governance/fiscal-federalism-2014_9789264204577-en\#.WRw8vmh96Uk \#page1>. 